\title{
Yield and nutritive value of mechanically processed corn silage from an integrated crop-livestock system
}

\section{Produtividade e valor nutritivo de silagens de milho mecanicamente processadas em sistema integrado de produção agropecuária}

\author{
Maria Helena de Oliveira ${ }^{1 *}$; Ciniro Costa ${ }^{2}$; Cristiano Magalhães Pariz ${ }^{3}$; \\ Paulo Roberto de Lima Meirelles ${ }^{2}$; Marcelo Andreotti4; André Michel de Castilhos ${ }^{5}$; \\ Daniel Martins de Souza ${ }^{6}$; Nelson de Araújo Ulian ${ }^{7}$
}

\section{Highlights}

The intercropping system does not compromise the yield of either crop.

Harvesting corn at $45 \mathrm{~cm}$ above soil increases the proportion of grain in silage.

The mechanically processed silage had higher nutritive value.

\begin{abstract}
The objective of this study was to evaluate the yield and nutritional value of silage made from corn intercropped with marandu palisadegrass (Urochloa brizantha cv. Marandu) in an integrated crop-livestock system. The corn was harvested at different maturity stages and cutting heights and was processed or not before ensiling. The experimental design was a randomized block with four replications in a $2 \times 2 \times 2+1$ factorial scheme. The treatments were composed of silage corn intercropped with marandu palisadegrass harvested at two cutting heights ( 20 or $45 \mathrm{~cm}$ ) and two stages of maturity $(1 / 4$ of the kernel milk line or kernel physiological maturity) and subjected to two methods of processing (crushing or not crushing). A control treatment composed of conventionally grown corn silage was also included. The total dry matter yields of

1 PhD Student, Department of Animal Nutrition and Breeding, School of Veterinary Medicine and Animal Science, UNESP, Botucatu, SP, Brazil. E-mail: ma.mariahelena@hotmail.com

2 Profs., PhD, Department of Animal Nutrition and Breeding, School of Veterinary Medicine and Animal Science, UNESP, Botucatu, SP, Brazil. E-mail: ciniro.costa@unesp.br; paulo.meirelles@unesp.br

3 Animal Scientist PhD, Department of Animal Nutrition and Breeding, School of Veterinary Medicine and Animal Science, UNESP, Botucatu, SP, Brazil. E-mail: cmpzoo@gmail.com

${ }^{4}$ Prof. PhD, Department of Plant Health, Rural Engineering and Soil, FE/UNESP, Ilha Solteira, SP, Brazil. E-mail: dreotti@ agr.feis.unesp.br

${ }^{5}$ Animal Scientist PhD, Department of Animal Nutrition and Breeding, School of Veterinary Medicine and Animal Science, UNESP, Botucatu, SP, Brazil. E-mail: michel.castilhos@unesp.br

${ }^{6}$ PhD Student, Department of Animal Nutrition and Breeding, School of Veterinary Medicine and Animal Science, UNESP, Botucatu, SP, Brazil. E-mail: souzadm.zoo@gmail.com

7 Animal Scientist MSc, School of Veterinary Medicine and Animal Science, UNESP Botucatu, SP, Brazil. E-mail: nelson. ulian@yahoo.com

* Author for correspondence
\end{abstract}

Received: July 07, 2020 - Approved: Sept. 27, 2020 
both crops did not differ significantly among treatments, demonstrating the viability of the intercropping system for both forage species. Although the dry matter content of the corn plants was higher at the time of ensiling, the fermentative and nutritive quality of the silages was not affected. Increasing the cutting height increased the grain content of the forage mass and also avoided harming the development of the intercropped grass. The silages from the physiological maturity treatment and from the processed treatment had the best quality.

Key words: Harvest height. Kernel processing. Maturity stage.

\section{Resumo}

O objetivo deste trabalho foi avaliar a produtividade e valor nutritivo de silagens de milho em consórcio com Urochloa brizantha cv. Marandu (capim-marandu) em sistema integrado de produção agropecuária colhidas em diferentes maturidades, alturas de corte e submetidas ou não a processamento mecânico antes da ensilagem. $\mathrm{O}$ delineamento experimental foi o de blocos casualizados, com quatro repetições, em esquema fatorial $2 \times 2 \times 2+1$, sendo os tratamentos compostos por silagem de milho em consórcio com o capimmarandu, em duas alturas de corte $(20$ e $45 \mathrm{~cm}$ ), dois estádios de colheita (1/4 do grão leitoso e maturidade fisiológica) e duas formas de processamento da massa antes da ensilagem (esmagado e não esmagado) e o cultivo exclusivo do milho como testemunha. A produtividade de massa seca das plantas não diferiu estatisticamente entre os tratamentos, demonstrando a viabilidade do consórcio entre as culturas. Embora o teor de matéria seca das plantas de milho no momento da ensilagem ter sido superior ao recomendado, não houve comprometimento da qualidade das silagens. A elevação da altura de corte do milho causa incremento na proporção de grãos na massa ensilada, além de não comprometer o desenvolvimento subsequente do capim em consórcio. As silagens oriundas de plantas colhidas no ponto de maturidade fisiológica e as submetidas ao processamento mecânico foram as que apresentaram melhor qualidade fermentativa e nutritiva.

Palavras-chave: Altura de corte. Estádio fisiológico. Processamento.

\section{Introduction}

Integrated crop-livestock systems (ICLSs) are a sustainable practice that provides a better use of land than conventional systems, good forage quality throughout the year and straw for no-tillage systems (NTSs). This technique allows diversification, rotation, and intercropping of plants and animals in the same area and is largely used in South America due to its productive, economic and environmental benefits (Moraes et al., 2019).

Intercropping cash crops with tropical grasses has had great positive effects when it does not alter the productivity of either species and supports livestock production practices by providing high-quality silage (Souza et al., 2019) and pasture (Pariz et al., 2017; Costa et al., 2017).

Corn is one of the most commonly used forages for silage production since it provides high yields per area, high dry matter (DM) content, chemical and nutritional quality, low buffering capacity, high nutritional value from its kernels, easy mechanical harvesting and flexibility of use (Ferraretto, Shaver, \& Luck, 2018). Furthermore, some strategies can be adopted to enhance the energy quality of corn 
silage, such as harvesting late-maturity corn plants, which have more starch in their grain; increasing cutting heights, which increases the proportion of grain in the forage mass (Caetano et al., 2011; Rezende, Watanabe, Silveira Rabelo, Silveira Rabelo, \& Nogueira, 2015) and preserves the development of the intercropped grass after harvesting the corn for silage (Pariz et al., 2017).

Corn plants harvested at physiological maturity have more starch in their grain than plants harvested at earlier stages; consequently, they show greater lignification in their vegetative fraction due to crop senescence. For this reason, increasing the cutting height of corn plants to exclude the lower vegetative fractions decreases the proportion of fibrous components in silage (Caetano et al., 2011; Rezende et al., 2015), thereby increasing the energy concentration of the silage. On the other hand, the delay in harvesting leads to an increase in the vitreousness of the kernel (Ferraretto et al., 2018), decreasing its digestibility.

The mechanical processing of corn plants, especially those harvested at late maturities, during harvest is an effective strategy for improving the digestibility of silage (Hara \& Tanigawa, 2010) as it breaks the pericarp and exposes the starch granules of the grain. In addition, physical processing also damages the vegetative part of the plant, increasing fiber degradation and significantly improving the quality of the silage (Silveira, Nardi, Silveira, \& Costa, 2014).

The objective of this work was to evaluate the nutritional value and fermentation quality of silages from corn plants grown intercropped with marandu palisadegrass under a no-tillage system. To this end, the corn was harvested at two stages of maturity with two cutting heights, and two methods of processing were used before ensiling.

\section{Material and Methods}

This experiment was carried out at the Department of Forage Production, Lageado Experimental Farm, at the School of Veterinary Medicine and Animal Science (FMVZ/UNESP) in Botucatu city, SP, Brazil (22 $51^{\prime} 01^{\prime \prime} S$, $48^{\circ} 25^{\prime} 28^{\prime \prime} \mathrm{W}$, at $777 \mathrm{~m}$ above sea level). The soil is classified as a Typic Haplorthox or Latossolo Vermelho distroférrico (Santos et al., 2006) and contains 630,90 , and $280 \mathrm{~g} \mathrm{~kg}^{-1}$ clay, silt, and sand, respectively. The climate of the region is classified as Cwa, i.e., tropical with dry winters and hot and rainy summers, according to Köppen-Geiger. The monthly rainfall and the maximum and minimum temperatures during the experimental period are shown in Figure 1. 


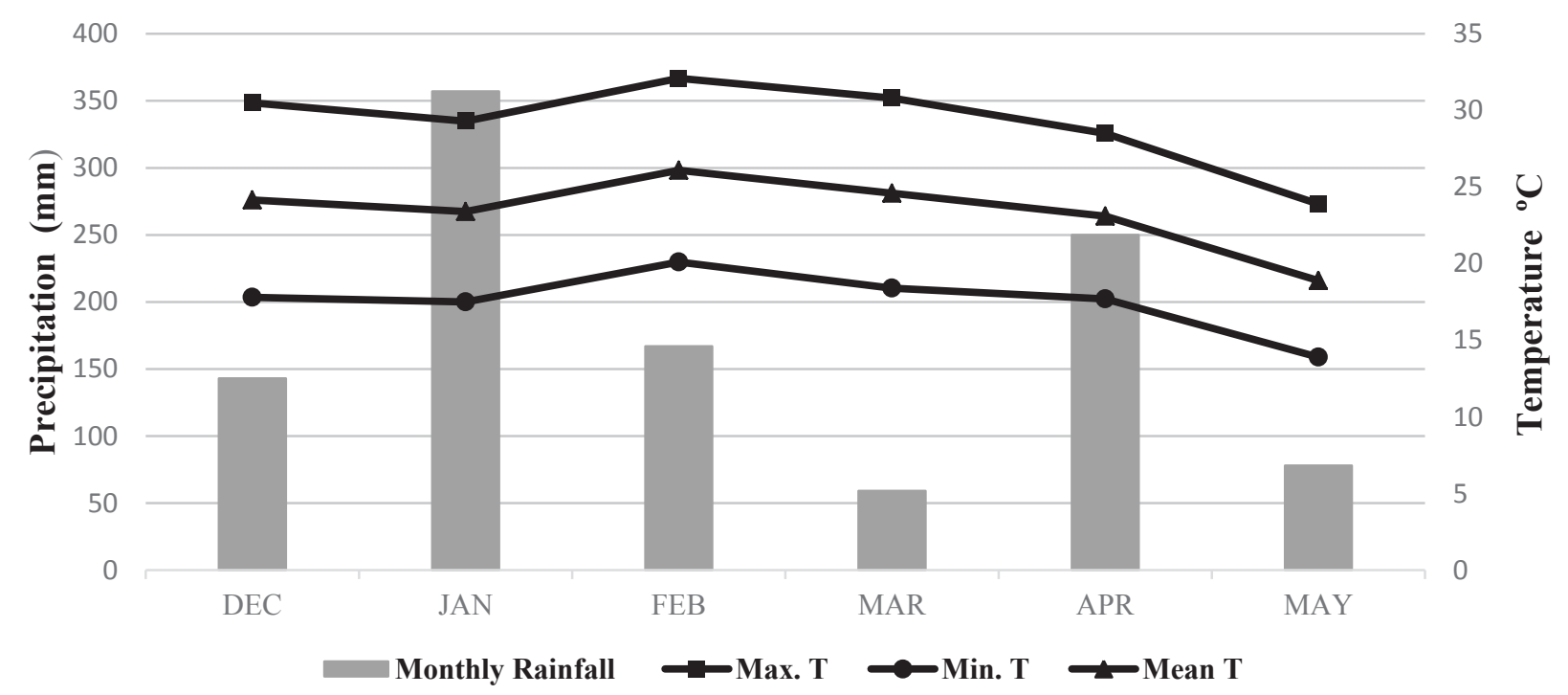

Figure 1. Monthly rainfall $(\mathrm{mm})$, maximum, minimum and mean temperatures $\left({ }^{\circ} \mathrm{C}\right)$ during the experimental period.

Source: Meteorological station FCA/UNESP, Botucatu, SP.

Before the experimental growing season, an integrated crop-livestock system (ICLS) with corn intercropped with Urochloa hybrids in the harvest season and oversowing of yellow oat (Avena byzantina C. Kock) for winter grazing by lambs between August and November was used in the area.

Before sowing, the regrowth of signal grass and annual broadleaf weeds was desiccated with $1.4 \mathrm{~L} \mathrm{ha}^{-1}$ glyphosate for straw formation and to continue the nontillering system. Subsequently, furrow opening and straw cutting were performed, followed by scarification. After that, corn (Zea mays L.) simple hybrid 2B587 HX, which exhibits early maturity, was sown on the third week of December at a 0,05 $\mathrm{m}$ depth with a no-tillage drill at a row spacing of $0.45 \mathrm{~m}$. The desired final stand density was 78,000 plants ha ${ }^{-1}$.

In the intercropping treatments, the seeds of marandu palisadegrass were mixed with fertilizer and sown simultaneously with the corn at a 0,08 $\mathrm{m}$ depth in the corn rows (Pariz et al., 2017) at a seed density of $11 \mathrm{~kg} \mathrm{ha}^{-1}(51 \%$ pure live seed).

For mineral fertilization, $420 \mathrm{~kg} \mathrm{ha}^{-1}$ of 08-28-16 N-P-K fertilizer was applied at sowing. Topdressing mineral fertilization was performed between corn rows by applying 150 $\mathrm{kg} \mathrm{ha}^{-1} \mathrm{~N}$ (333 kg ha-1 of urea) and $90 \mathrm{~kg} \mathrm{ha}^{-1} \mathrm{~K}_{2} \mathrm{O}$ (150 kg ha-1 of potassium chloride) (Cantarella, Raji \& Camargo, 1997) when the corn plants had five expanded leaves.

The experimental design was a randomized block with four replications in a $2 \times 2 \times 2+1$ factorial scheme. The treatments were composed of silage corn intercropped with marandu palisadegrass harvested at two cutting heights (20 or $45 \mathrm{~cm}$ ) and two harvest stages (1/4 of the kernel milk line and kernel physiological maturity) and subjected to two methods of processing (crushing and not crushing). In addition, there was a control treatment composed exclusively of silage 
corn. The control treatment was harvested at $0,20 \mathrm{~m}$ above the soil surface and was not mechanically processed, representing the common practice on commercial properties.

The absence of rainfall during the experimental period caused a delay in seedling emergence for the crops, which occurred 16 days after sowing for corn and 18 days after sowing for marandu palisadegrass. The delay in emergence did not affect the initial corn plant stand density $\left(78,000\right.$ plants ha $\left.^{-1}\right)$; however, it did lead to initial competition between crops.

At the end of January (35 days after sowing), $16 \mathrm{~g} \mathrm{ha}^{-1}$ a.i. of nicosulfuron and 2.0 $\mathrm{L} \mathrm{ha-1}$ a.i. of atrazine were applied to reduce the initial growth of the grass seedlings and to control the emergence of some annual broadleaf weeds.

The harvesting times were determined according to visual observations of the corn grain milk stage. Thus, the harvest occurred at 117 and 139 days after sowing for the harvests at 1/4 milk line and physiological maturity, respectively.

The harvested forage was collected manually in the field and chopped with a stationary chopper. The forage was mechanically processed before ensiling with wet grain silage machine, which crushed the material with cracker rolls turning in opposite directions.

PVC mini-silos of $400 \mathrm{~mm}$ in length and $100 \mathrm{~mm}$ in diameter were used as the experimental silos and could hold approximately $2.0 \mathrm{~kg}$ of green matter at a density of $600 \mathrm{~kg} \mathrm{~m}^{3}$ (green mass). At the base of the silo, bags containing $400 \mathrm{~g}$ of sterile sand were used to quantify the effluent loss during storage. The mass of forage added to each experimental silo was compacted for storage by pressing for 5 minutes with an adapted hydraulic press. The silos were weighed, sealed with PVC lids equipped with Bunsen valves to release the gases produced by fermentation and stored at the Forage Production Sector of FMVZ/UNESP for 90 days after the silage tests.

Before harvesting, the final plant population was measured by sampling one meter of the four central rows and extrapolating the sample to plants per hectare. The contributions of corn and marandu palisadegrass to the final composition of the ensiled forage mass as well as the dry matter yields of corn (DMY corn) and marandu palisadegrass (DMY MP), as percentages, were determined at the time of ensiling after collecting samples from the harvested material.

When the silos were opened, four, 300 g samples were collected, dried under forcedair circulation at $65^{\circ} \mathrm{C}$ for 72 hours, and milled in a Wiley-type mill with a $1 \mathrm{~mm}$ mesh sieve to determine the $\mathrm{DM}$, crude protein $(\mathrm{CP})$, neutral detergent fiber (NDF), and acid detergent fiber (ADF) contents according to the methods of the Association of Official Analytical Chemists [AOAC] (1995). The total digestible nutrient (TDN) content was determined using the methodology proposed by Weiss and adopted by the National Research Council (NRC, 2001).

The fermentation parameters, such as the ratio of ammoniacal nitrogen to total nitrogen $\left(\mathrm{N}-\mathrm{NH}_{3} / \mathrm{TN}\right)$ and $\mathrm{pH}$, were determined as described in AOAC (1995). The content of organic acids (lactic and acetic) was determined at a wavelength of $210 \mathrm{~nm}$ in a Shimadzu SPD-10A VP high-performance liquid chromatograph (HPLC) coupled to an ultraviolet detector (UV) according to Kung and 
Shaver (2001). The production of gas (\% DM) and effluent in $\mathrm{kg} \mathrm{t}^{-1}$ of the green matter (GM) was estimated using the equations described by Jobim, Nússio, Reis and Schmidt (2007).

All data were subjected to comparisons of Tukey test averages at the level of $5 \%$ significance with the statistical software SisVar (Ferreira, 2015) version 5.6. Initially, a mathematical model was developed and subjected to triple evaluation, but, due to the lack of significance $(P<0.05)$, the model was removed from the analysis.

\section{Results and Discussion}

Managing the events that occur in the different phases of intercropped crop development is essential since competition between species compromises the productive characteristics that are responsible for reducing production costs. The absence of rainfall at the beginning of the experimental period (Figure 1) resulted in a delay in the emergence of corn and marandu palisadegrass, which occurred 16 and 18 days, respectively, after sowing. The difference of two days in emergence caused initial competition between the crops, which required the application of a high dose of nicosulfuron-based herbicide to mitigate the growth of marandu grass, as recommended by Pariz et al. (2011).
The mean productive parameters of the crops are shown in Table 1. The dry matter yield (DMY) of corn was, on average, $13,500 \mathrm{~kg} \mathrm{ha}^{-1}$, a value similar to those found by Buso, Machado, Ribeiro and Silva (2018) in tests of five corn hybrids in monoculture for silage. For marandu palisadegrass, yields of 208.25 and $523.13 \mathrm{~kg} \mathrm{ha}^{-1}$ were found at the $1 / 4$ milk line and maturity stages, respectively, and these yields were significantly different $(P<0.05)$. This difference was expected and was due to the 22 additional days of marandu palisadegrass growth when the corn was harvested at maturity than when the corn was harvested at 1/4 milk line. Similarly, there was a significant difference between the average proportions of marandu grass in the ensiled mass, 2.9 and $7.8 \%$, respectively, when the corn was harvested at the 1/4 milk line stage and at the kernel maturity stage; these values are in line with those observed for the DMY of the grass in both harvest stages.

Neumann etal. (2020), in evaluating corn hybrids for silage, found an average of 39 and $46 \%$ of grain in the plant dry mass, respectively, at the 1/4 milk line and kernel maturity stages. Costa et al. (2017), in evaluating three maize cultivation systems for whole-plant silage (single-crop, corn intercropped with marandu grass and corn intercropped with Tanzania grass), did not find a significant difference in the percentage of grains in the plant dry mass, with means ranging from 36.8 to $41.1 \%$; these values are lower than the findings in this study. 


\section{Table 1}

Dry matter yield of corn (DMY corn), dry matter yield of marandu palisadegrass (DMY Marandu), proportion of grains and proportion of marandu palisadegrass (\%) in silages from different maturities and cutting heights

\begin{tabular}{|c|c|c|c|c|}
\hline & DMY Corn & DMY Marandu & Grains & Marandu \\
\hline & \multicolumn{2}{|c|}{-----------Kg ha-1 ---------- } & \multicolumn{2}{|c|}{---------- (\%) ---------- } \\
\hline \multicolumn{5}{|l|}{ Maturity } \\
\hline $1 / 4 \mathrm{ML}^{1}$ & 13,338 & 208.25 B & 51.25 & $2.88 \mathrm{~B}$ \\
\hline $\mathrm{PM}^{2}$ & 12,821 & $523.13 \mathrm{~A}$ & 50.88 & $7.75 \mathrm{~A}$ \\
\hline C & 14,713 & ----- & 42.25 & ----- \\
\hline \multicolumn{5}{|l|}{ Cutting height } \\
\hline $20 \mathrm{~cm}$ & 13,345 & 370.25 & $48.00 \mathrm{~B}$ & 5.00 \\
\hline \multirow[t]{2}{*}{$45 \mathrm{~cm}$} & 12,815 & 361.13 & $54.13 \mathrm{~A}$ & 5.63 \\
\hline & & ANOVA & & \\
\hline V.S & \multicolumn{4}{|c|}{$P$ Value } \\
\hline Maturity & 0.4480 & $<0.0001$ & 0.0785 & $<0.0001$ \\
\hline Cutting height & 0.4458 & 0.0127 & 0.0093 & \\
\hline
\end{tabular}

Mean values followed by different uppercase letters in the same column are significantly different by Tukey's test at $5 \%$ probability.

1 1/4 Milk Line; ${ }^{2}$ Physiological maturity.

A significant difference $(P<0.05)$ in the grain percentage was found only in relation to the cutting heights, with an increase in this parameter in silage harvested at the higher cutting height (45 $\mathrm{cm}$ above the soil surface). This increase occurred because the higher cutting height that eliminated the dilution effect from the proportion of stalks and leaves that occurs when the plant is cut at lower cutting heights (Caetano et al., 2011; Rezende et al., 2015).

It is recommended that the corn harvest for silage occur after measuring the DM content of the plants and that this value be close to 35\% (Ferraretto et al., 2018) to ensure a satisfactory fermentation process and final product quality. The DM levels found at the time of harvest were significantly different $(P<0.05)$ and were above the recommended level since they presented means above $49 \%$ (Table 2). This is due to the adverse conditions related to the low rainfall that occurred during the experimental period, which resulted in a drought in the vegetative part of the plant before grain filling. For this reason, it was decided to carry out the harvest based on visual observations of the starch deposition in the corn kernels rather than on the plant's DM content. 
Table 2

Dry matter contents of corn plants before ensiling as a function of the treatments

\begin{tabular}{ccccccc} 
& \multicolumn{2}{c}{$1 / 4 \mathrm{ML}^{1}$} & \multicolumn{2}{c}{$\mathrm{PM}^{2}$} & \multirow{2}{*}{ Control } & $P$ \\
\cline { 2 - 5 } Treatments & $20 \mathrm{~cm}$ & $45 \mathrm{~cm}$ & $20 \mathrm{~cm}$ & $45 \mathrm{~cm}$ & & \\
\cline { 2 - 5 } & $51,50 \mathrm{~A}$ & $56,00 \mathrm{AB}$ & $63,75 \mathrm{BC}$ & $69,00 \mathrm{C}$ & $49,25 \mathrm{~A}$ & $<0,0001$
\end{tabular}

Mean values followed by different uppercase letters in the same row are significantly different by Tukey's test at $5 \%$ probability.

1 1/4 Milk Line; ${ }^{2}$ Physiological maturity.

The intrinsic characteristics of each hybrid and detrimental edaphoclimatic conditions can alter the degree of maturation in corn plants, promoting an increase in the DM content of the plants. Likewise, the physiological stage of the plant can also lead to an increase in DM content; at more advanced stages, higher levels of DM are observed due to plant senescence, which causes a decrease in water levels and an increase in the fiber fraction. In addition, at the same physiological stage, increasing the cutting height of the plants increases the DM content due to the higher proportion of grain and the lower proportions of stems and leaves, as previously discussed. In the present study, there were differences of 4.5 and $5.25 \%$ between the silages harvested at 20 and $45 \mathrm{~cm}$ above the soil surface at the $1 / 4$ milk line and maturity stages, respectively.
The losses that occurred during the fermentation process were evaluated through the quantification of gases and effluents and are shown in Table 3 together with the levels of lactic acid, acetic acid, ammoniacal nitrogen and $\mathrm{pH}$. In general, small losses from gases and effluents were observed. Although they differed significantly among the treatments evaluated, the gas losses (mean 3.7\% DM) were lower than those found in the literature. Junges, Schmidt, Novinski and Daniel (2013) compared the production of gases from corn silages with and without the use of inoculants and did not observe differences in the loss of gases between treatments, which made up an average of 4.5\% DM. Excessive gas losses from silage occur under fermentation conditions due to undesirable microorganisms. 


\section{Table 3}

Gases, effluents, latic acid, acetic acid, ammoniacal nitrogen to total nitrogen ratio $\left(\mathrm{N}-\mathrm{NH}_{3} / \mathrm{N}\right)$ and pH of silages from different maturities, cutting heights and mechanical processing

\begin{tabular}{|c|c|c|c|c|c|c|}
\hline & $\begin{array}{l}\text { Gases } \\
\% \text { DM }\end{array}$ & $\begin{array}{l}\text { Effluents } \\
\mathrm{kg} \mathrm{t}^{-1} \mathrm{GM}\end{array}$ & Latic Acid & Acetic Acid & $\mathrm{N}-\mathrm{NH}_{3}$ & $\mathrm{pH}$ \\
\hline \multicolumn{7}{|l|}{ Maturity } \\
\hline $1 / 4 \mathrm{ML}^{1}$ & $4.88 \mathrm{~B}$ & 3.63 & $4.00 \mathrm{~A}$ & $2.06 \mathrm{AB}$ & $4.06 \mathrm{~A}$ & $3.79 \mathrm{~A}$ \\
\hline $\mathrm{PM}^{2}$ & $3.00 \mathrm{~A}$ & 3.63 & $3.13 \mathrm{~B}$ & $1.50 \mathrm{~A}$ & $3.38 \mathrm{~A}$ & $3.94 \mathrm{~B}$ \\
\hline $\mathrm{C}$ & $2.00 \mathrm{~A}$ & 3.00 & $4.00 \mathrm{~A}$ & $2.50 \mathrm{~B}$ & $6.50 \mathrm{~B}$ & $3.80 \mathrm{~A}$ \\
\hline \multicolumn{7}{|l|}{ Cutting height } \\
\hline $20 \mathrm{~cm}$ & 3.06 & $3.25 \mathrm{~A}$ & 3.75 & 1.69 & 3.69 & $3.82 \mathrm{~A}$ \\
\hline $45 \mathrm{~cm}$ & 4.81 & $4.00 \mathrm{~B}$ & 3.38 & 1.88 & 3.75 & $3.90 \mathrm{~B}$ \\
\hline \multicolumn{7}{|l|}{ Processing } \\
\hline$P^{3}$ & $2.94 \mathrm{~A}$ & $4.00 \mathrm{~B}$ & 3.69 & 1.81 & 3.75 & $3.81 \mathrm{~A}$ \\
\hline UP 4 & $4.94 \mathrm{~B}$ & $3.25 \mathrm{~A}$ & 3.44 & 1.75 & 3.69 & $3.92 \mathrm{~B}$ \\
\hline \multicolumn{7}{|c|}{ ANOVA } \\
\hline V.S & \multicolumn{6}{|c|}{$P$ Value } \\
\hline Maturity & 0.0015 & 0.0500 & 0.0005 & 0.0033 & $<0.0001$ & $<0.0001$ \\
\hline Cutting height & 0.0615 & 0.0279 & 0.2095 & 0.5849 & 0.8586 & 0.0462 \\
\hline Processing & 0.0307 & 0.0279 & 0.4067 & 0.8559 & 0.8586 & 0.0075 \\
\hline
\end{tabular}

Mean values followed by different uppercase letters in the same column are significantly different by Tukey's test at $5 \%$ probability.

${ }^{1}$ 1/4 Milk Line; ${ }^{2}$ Physiological maturity; ${ }^{3}$ Processed; ${ }^{4}$ Unprocessed.

The losses by effluents observed were small due to the high DM content of the silages in this experiment. The highest content $4.0 \mathrm{~kg}$ $\mathrm{t}^{-1}$ green matter) was observed in silages from plants harvested $45 \mathrm{~cm}$ from the soil and in those that were processed, but this value was lower than the $6.04 \mathrm{~kg} \mathrm{t}^{-1}$ green matter found by Junges et al. (2013).

In terms of acid production, as a strong acid, lactic acid is considered the most efficient for decreasing $\mathrm{pH}$, thus, preserving the nutritional and sanitary quality of the ensiled mass (Dunière, Sindou, Chaucheyras-Durand, Chevallier, \& Thévenot-Sergentet 2013). In addition, it is found in higher concentrations in silage than other acids (Kung, Shaver, Grant,
\& Schmidt, 2018). The levels of lactic acid did not differ $(P>0.05)$ due to the cutting height or processing and were within the recommended range for corn silage ( 2 to $4 \%$ DM) (Kung et al., 2018). There was a difference $(P<0.05)$ in lactic acid levels related to the physiological stage of the plant, resulting from the differences in DM content between cuts. The silages in the control group and those harvested at 1/4 milk line had the highest lactic acid levels (4\%). This similarity occurred because they were harvested at the same physiological stage, at which the plants had lower DM concentrations.

Acetic acid is found at the secondhighest concentrations in silage (Kung et al., 2018); it is considered weak in terms of reducing 
the $\mathrm{pH}$ of silage but has antifungal action (Muck et al., 2018). There was a difference (P $<0.05$ ) in acetic acid content only in relation to the physiological stages, following the pattern observed for lactic acid, and the acetic acid values were within the acceptable limit for corn silage, which varies from 1 to $3 \%$ of the DM (Kung et al., 2018).

The ammoniacal nitrogen $\left(\mathrm{N}-\mathrm{NH}_{3}\right)$ content is an indicator of the total protein degraded during the fermentation process and is higher in high-moisture silage. The levels of $\mathrm{N}-\mathrm{NH}_{3}$ were below those recommended by Kung et al. (2018) for corn silage (5 to $7 \%$ of the total $\mathrm{N}$ ) in all experimental conditions in this study. There was a difference $(P<0.05)$ in $\mathrm{N}-\mathrm{NH}_{3}$ content only between ensiled plants harvested at different stages of maturity, and the difference was due to the difference in the DM content.

The experimental treatments had an effect $(\mathrm{P}<0.05)$ on the silage $\mathrm{pH}$; however, all values were within the recommended range for whole-corn silage (3.7 to 4.0) (Kung et al., 2018) and were consistent with the findings of Costa et al. (2017).

The silage from the lower-cut plants had lower $\mathrm{pH}$ values than the silage from the higher-cut plants. Lynch, Baah and Beauchemin (2015), in evaluating cutting heights for silage corn, observed the same pattern and suggested that it is due to the inclusion, in the lower-cut silage, of a higher proportion of the plant's vegetative fraction, which has low buffering capacity and requires less lactic acid to reduce the $\mathrm{pH}$ value. It is also noted that the processed silage showed lower $\mathrm{pH}$ values than unprocessed silage. This difference may be due to the positive effects of processing, namely, particle size reduction improved compaction and consequently improved fermentation profile, which result in greater lactic fermentation compared with that in unprocessed silage (Hara \& Tanigawa, 2010).

The $\mathrm{pH}$ assessment combined with that of organic acids and $\mathrm{N}-\mathrm{NH}_{3}$ (Kung et al., 2018) provides an overview of the fermentation process that occurred during the storage period. In general, given the high DM content obtained when the plants were cut, it can be said that the fermentation process in all treatments occurred satisfactorily.

The chemical composition of the silages is shown in Table 4. The average CP content was $7.24 \%$ DM, which is close to that found by Buso et al. (2018) in a study evaluating corn hybrids for silage. There was a significant difference between CP levels in the different cutting height treatments; this is different from what was observed by Marquardt, Jobim, Bueno and Ribeiro (2017), who, when working with silage corn harvested at 20 and $40 \mathrm{~cm}$ above the ground, did not observe any difference between the levels of $\mathrm{CP}$; however, none of these treatments came from intercropping systems with forages. 
Table 4

Crude protein (CP), neutral detergent fiber (NDF), acid detergent fiber (ADF) and total digestible nutrients (TDN) contents of silages from different maturities, cutting heights and mechanical processing

\begin{tabular}{|c|c|c|c|c|}
\hline & $\mathrm{CP}$ & NDF & ADF & TDN \\
\hline \multicolumn{5}{|l|}{ Maturity } \\
\hline $1 / 4 \mathrm{ML}^{1}$ & 7.18 & $62.76 \mathrm{AB}$ & $27.88 \mathrm{~A}$ & $57.61 \mathrm{AB}$ \\
\hline $\mathrm{PM}^{2}$ & 7.15 & $58.70 \mathrm{~A}$ & $24.86 \mathrm{~A}$ & $59.31 \mathrm{~A}$ \\
\hline $\mathrm{C}$ & 7.65 & $65.60 \mathrm{~B}$ & $31.45 \mathrm{~B}$ & $56.43 \mathrm{~B}$ \\
\hline \multicolumn{5}{|l|}{ Cutting height } \\
\hline $20 \mathrm{~cm}$ & $7.51 \mathrm{~A}$ & 61.29 & $28.55 \mathrm{~B}$ & 58.23 \\
\hline $45 \mathrm{~cm}$ & $6.82 \mathrm{~B}$ & 60.17 & $24.20 \mathrm{~A}$ & 58.70 \\
\hline \multicolumn{5}{|l|}{ Processing } \\
\hline P 3 & 7.19 & $57.63 \mathrm{~A}$ & $24.08 \mathrm{~A}$ & $59.75 \mathrm{~A}$ \\
\hline UP 4 & 7.15 & 63.82 B & 28.66 B & $57.17 \mathrm{~B}$ \\
\hline \multicolumn{5}{|l|}{ ANOVA } \\
\hline V.S & P Value & & & \\
\hline Maturity & 0.0362 & 0.0011 & 0.0001 & 0.0011 \\
\hline Cutting height & 0.0013 & 0.6248 & 0.0078 & 0.6241 \\
\hline Processing & 0.8614 & 0.0036 & 0.0047 & 0.0036 \\
\hline
\end{tabular}

Mean values followed by different uppercase letters in the same column are significantly different by Tukey's test at $5 \%$ probability.

${ }_{1}^{1} 1 / 4$ Milk Line; ${ }^{2}$ Physiological maturity; ${ }^{3}$ Processed; ${ }^{4}$ Unprocessed.

The silages harvested at 20 and 45 $\mathrm{cm}$ above the soil showed CP contents of 7.5 and $6.8 \%$, respectively. This small but significant difference of $0.62 \%$ may be due to the dilution effect caused by the increase in the cutting height, in other words, the higher cutting height results in a higher proportion of starch and lower proportions of stems and leaves in the total mass (Caetano et al., 2011; Rezende et al., 2015). In addition, in silages from plants grown in intercropping systems with forages, the increase in cutting height and the consequent decrease in grass content reduces the increase in nutritional value of the species in the ensiled mass and benefits grass regrowth after harvesting (Pariz et al., 2017). Likewise, the lower CP levels of silage made from intercropped corn (7.5\%) than of silage made from monoculture corn (7.7) harvested at $20 \mathrm{~cm}$ from the soil may be a consequence of the dilution effect of the inclusion of marandu palisadegrass.

The NDF content in ruminant feed is extremely important since NDF promotes ruminal health and well-being; however, it is highly correlated with dry matter intake, and high NDF levels limit feed consumption. For this reason, the measurement of this characteristic is an important tool in the formulation of diets (Hristov et al., 2020). The ADF fraction is 
correlated with digestibility, and feed is less digestible when the ADF content is above $40 \%$ of the DM (Khan, Yu, Ali, Cone, \& Hendriks 2015).

There was a difference $(P<0.05)$ in the NDF and ADF contents of silages from plants harvested at different stages. The silages from the intercropping system showed better results for both variables than the silages from the control treatment. Cutting at the kernel maturity stage provided silage with the optimal NDF and ADF contents, at 58.7 and $24.9 \%$ on average, respectively. These values are close to those found by Costa et al. (2017), who, when evaluating a corn intercropping system with marandu grass that was harvested at maturity for the production of silage, found mean NDF and ADF values of 56.1 and $25.6 \%$ $D M$, respectively.

There was no difference $(P>0.05)$ in NDF content due to the cutting heights, corroborating the findings of Marquardt et al. (2017), who evaluated cutting heights of 20 and $40 \mathrm{~cm}$ above the soil surface. For the $A D F$, the elevation of the cutting height had a positive effect $(P<0.05)$, since the silages from the cut at $45 \mathrm{~cm}$ from the soil showed more satisfactory ADF values.

The NDF and ADF fractions experienced a positive effect $(P<0.05)$ from processing before ensiling, which resulted in the lowest values for both characteristics. The processing of plant grains and vegetative parts causes cellular disruption, which leaks the cell contents and consequently improves the availability of nutrients in silage (Silveira et al., 2014). This explanation is also valid for the TDN values, as they were higher $(P<0.05)$ in the crushed silage than in the unprocessed silage.
The estimated levels of TDN indicate the energy content of food, which is reduced in the presence of high levels of fiber. The means for this parameter differed significantly $(P<0,05)$ in the different harvest stage and processing treatments; TDN was higher in the silages from plants harvested at kernel maturity and those subjected to mechanical processing before ensiling.

\section{Conclusions}

Intercropping corn with marandu palisadegrass does not alter the productive characteristics of the corn or the fermentation or nutritional parameters of the silages.

The silages from plants harvested at physiological maturity and those that were mechanically processed had the best nutritional value.

The high cutting height for the corn intercropped with grasses for silage provided a higher proportion of grains in the silage and did not harm grass tillering in the integrated croplivestock system.

Mechanically processing the forage mass before ensiling expanded the corn harvesting window for the production of silage with high nutritional value.

\section{Acknowledgments}

To Fundação de Amparo à pesquisa do Estado de São Paulo (FAPESP) for grants (Process FAPESP n²011/12155-3). 


\section{References}

Association of Official Analytical Chemists (1995). Official methods of analysis (16nd ed.). Washington, D.C.: AOAC.

Buso, W. H. D., Machado, A. S., Ribeiro, T. B., \& Silva, L. O. (2018). Produção e composição bromatológica da silagem de híbridos de milho sob duas alturas de corte. Journal of Neotropical Agriculture, 5(4), 74-80. doi: 10.32404/rean.v5i4.2682

Caetano, H., Oliveira, M. D. S. D., Freitas, J. E. D., Jr., Rêgo, A. C. D., Rennó, F. P., \& Carvalho, M. V. D. (2011). Avaliação de cultivares de milho colhido em duas alturas de corte para ensilagem. Revista Brasileira de Zootecnia, 40(1), 12-19. doi: 10.1590/ S1516-35982011000100003

Cantarella, H., Raij, B. Van., Camargo, C. E. O. (1997). Cereais. In B. van RAIJ, H Cantarella, J. A. Quaggio, \& A. M. C. Furlani (Eds.), Recomendação de adubação e calagem para o Estado de São Paulo (2a ed., pp. 43-71). (Boletim Técnico, 100). Campinas: Instituto Agronômico; IAC.

Costa, N. R., Andreotti, M., Crusciol, C. A. C., Lima, C. G. D. R., Castilhos, A. M. D., Souza, D. M. D.,... Pariz, C. M. (2017). Yield and nutritive value of the silage of corn intercropped with tropical perennial grasses. Pesquisa Agropecuária Brasileira, 52(1), 63-73. doi: 10.1590/S0100-204X2017000100008

Dunière, L., Sindou, J., Chaucheyras-Durand, F., Chevallier, I., \& Thévenot-Sergentet, D. (2013). Silage processing and strategies to prevent persistence of undesirable microorganisms. Animal Feed Science and Technology, 182(1-4), 1-15. doi: 10.1016/j. anifeedsci.2013.04.006
Ferraretto, L. F., Shaver, R. D., \& Luck, B. D. (2018). Silage review: recent advances and future technologies for whole-plant and fractionated corn silage harvesting. Journal of Dairy Science, 101(5), 39373951. doi: 10.3168/jds.2017-13728

Ferreira, D. F. (2015). SISVAR: Sistema de análise de variância para dados balanceados. Versão 5.6, Lavras: DEX/UFLA.

Hara, S., \& Tanigawa, T. (2010). Effects of length of cut and mechanical processing on utilization of corn silage harvested at the black line stage of maturity by lactating dairy cows. Animal Science Journal, 81(2), 187-193. doi: 10.1111/j.1740-0929. 2009.00719.x

Hristov, A. N., Harper, M. T., Roth, G., Canale, C., Huhtanen, P., Richard, T. L., \& DiMarco, K. (2020). Effects of ensiling time on corn silage neutral detergent fiber degradability and relationship between laboratory fiber analyses and in vivo digestibility. Journal of Dairy Science, 103(3), 2333-2346. doi: 10. 3168/jds.2019-16917

Jobim, C. C., Nussio, L. G., Reis, R. A., \& Schmidt, P. (2007). Avanços metodológicos na avaliação da qualidade da forragem conservada. Revista Brasileira de Zootecnia, 36(1), 101-119. doi: 10.1590/ S1516 -35982007001000013

Junges, D., Schmidt, P., Novinski, C. O., \& Daniel, J. L. P. (2013). Additive containing homo and heterolactic bacteria on the fermentation quality of maize silage. Acta Scientiarum. Animal Sciences, 35(4), 371377. doi: 10.4025/actascianimsci.v35i4.18 833 
Khan, N. A., Yu, P., Ali, M., Cone, J. W., \& Hendriks, W. H. (2015). Nutritive value of maize silage in relation to dairy cow performance and milk quality. Journal of the Science of Food and Agriculture, 95(2), 238-252. doi: 10.1002/jsfa.6703

Kung, L., Jr., Shaver, R. D., Grant, R. J., \& Schmidt, R. J. (2018). Silage review: interpretation of chemical, microbial, and organoleptic components of silages. Journal of Dairy Science, 101(5), 4020-4033. doi: 10.3168/ jds.2017-13909

Kung, L., \& Shaver, R. (2001). Interpretation and use of silage fermentation analysis reports. Focus on Forage, 3(13), 1-5. Retrieved from https://fyi.extension.wisc. edu/forage/files/2016/10/Fermentation2. pdf

Lynch, J. P., Baah, J., \& Beauchemin, K. A. (2015). Conservation, fiber digestibility, and nutritive value of corn harvested at 2 cutting heights and ensiled with fibrolytic enzymes, either alone or with a ferulic acid esterase-producing inoculant. Journal of Dairy Science, 98(2), 1214-1224. doi: 10.3168/jds.2014-8768

Marquardt, F. I., Jobim, C. C., Bueno, A. V. I., \& Ribeiro, M. G. (2017). Altura de corte e adição de inoculante enzimo-bacteriano na composição químico-bromatológica e digestibilidade de silagens de milho avaliada em ovinos. Ciência Animal Brasileira, 18(1), 1-9. doi: 10.1590/10896891v18e-42888

Moraes, A., Carvalho, P. C. D. F., Crusciol, C. A. C., Lang, C. R., Pariz, C. M., Deiss, L., \& Sulc, R. M. (2019). Integrated croplivestock systems as a solution facing the destruction of Pampa and Cerrado biomes in South America by intensive monoculture systems. In G. Lemaire, P. C. F. Carvalho, S. Kronberg, \& S. Recous (Eds.), Agroecosystem diversity (pp. 257273). London: Academic Press.

Muck, R. E., Nadeau, E. M. G., McAllister, T. A., Contreras-Govea, F. E., Santos, M. C., \& Kung, L., Jr. (2018). Silage review: recent advances and future uses of silage additives. Journal of Dairy Science, 101(5), 3980-4000. doi: 10.3168/jds.2017-13839

National Research Council (2001). Nutrient requirements of dairy cattle (7nd ed). Washington, D.C.: National Academy Press.

Neumann, M., Venancio, B. J., Horst, E. H., Cristo, F. B., Petkowicz, K., Pontarolo, G. B.,... Martins, M. B. A. (2020). Corn hybrid silage quality according to harvesting time. Semina: Ciências Agrárias, 41(2), 369-382. doi: 10.5433/1679-0359.2020v41n2p369

Pariz, C. M., Andreotti, M., Bergamaschine, A. F., Buzetti, S., Costa, N. R., Cavallini, M. C.,... Luiggi, F. G. (2011). Yield, chemical composition and chlorophyll relative content of Tanzania and Mombaça grasses irrigated and fertilized with nitrogen after corn intercropping. Revista Brasileira de Zootecnia, 40(4), 728-738. doi: 10.1590/ S1516-35982011000400005

Pariz, C. M., Costa, C., Crusciol, C. A. C., Meirelles, P. R. D. L., Castilhos, A. M. D., Andreotti, M.,... Martello, J. M. (2017). Silage production of corn intercropped with tropical forages in an integrated croplivestock system with lambs. Pesquisa Agropecuária Brasileira, 52(1), 54-62. doi: 10.1590/S0100-204X2017000100007 
Rezende, A. V. D., Watanabe, D. J., Silveira Rabelo, F. H., Silveira Rabelo, C. H., \& Nogueira, D. A. (2015). Características agronômicas, bromatológicas e econômicas de alturas de corte para ensilagem da cultura do milho. Semina: Ciencias Agrarias, 36(2), 961-970. doi: 10.5433/1679-0359.2015v36n2p961

Santos, H. G., Jacomine, P. K. T., Anjos, L. H. C., Oliveira, V. A., Oliveira, J. B., Coelho, M. R.,... Cunha, T. J. F. (2006). Sistema brasileiro de classificação de solos. Rio de Janeiro: EMBRAPA Solos.
Silveira, T. F., Nardi, G. N. Jr., Silveira, J. P. F., \& Costa, C. (2014). Desempenho produtivo de novilhos Nelore confinados alimentados com silagem de milho processada. Boletim de Indústria Animal, 71(1), 39-46. doi: 10.17526/bia.v71n1

Souza, W. F., Costa, K. A. P., Guarnieri, A., Severiano, E. C., Silva, J. T., Teixeira, D. A. A.,... Dias, M. B. C. (2019). Production and quality of the silage of corn intercropped with Paiaguas palisadegrass in different forage systems and maturity stages. Revista Brasileira de Zootecnia, 4(1), 1-16. doi: $10.1590 /$ rbz4820180222 
